\title{
Penerapan Model Guided Discovery Learning Untuk Meningkatkan Pemahaman Konsep Matematis Mahasiswa
}

\author{
Guntur Maulana Muhammad ${ }^{1)} \mathrm{Karso}^{2)}$ \\ ${ }^{1)}$ Universitas Suryakancana, Cianjur, guntur@unsur.ac.id \\ ${ }^{2)}$ Universitas Pendidikan Indonesia, Bandung, karsoupi@yahoo.com \\ email.example@google.com
}

\begin{abstract}
This action research is based on the implementation Guided Discovery Learning (GDL) in the 2013 curriculum (K13) for education in Indonesia. Beside that the minimum completeness criteria, for space analytic geometry in Suryakancana University, has not been achieved yet. The aim of this study was to improve the mathematical conceptual understanding of students who were taking lectures on space analytic geometry. The sample consisted of two classes with many students of 19 and 22 respectively. This classroom action research was completed in two cycles. In the second cycle, the class absorption of each class was $78.95 \%$ and $77.27 \%$. Thus it can be concluded that the implementation of the GDL model can improve the ability to understand students' mathematical concepts, especially in the analytic geometry of space subject, and in general students provide a positive response to learning with the GDL model.
\end{abstract}

Keywords : Guided Discovery Learninng, Action Research, Conceptual Understanding

\section{PENDAHULUAN}

Pendidikan tinggi merupakan salah satu jenjang pendidikan yang dalam perspektif masyarakat merupakan wadah untuk mengem bangkan pola pikir manusia sebelum terjun ke kehidupan bermasyarakat. Di pendidikan tinggi pembelajar yang disebut mahasiswa mengalami fase-fase belajar yang mengarah pada pe ngembangan pengetahuan, pengubahan pola pikir ke arah logis dan realistis, serta pem biasaan diri untuk lebih mandiri. Sehingga diharapkan mahasiswa yang telah lulus dari pendidikan tinggi memiliki pengetahuan yang lebih dalam suatu bidang ilmu dengan mengedepankan rasionalitas dan memiliki karakter seorang yang mandiri.

Pendidikan tinggi memiliki otonomi untuk menyusun kurikulum sehingga setiap institusi pendidikan tinggi memiliki kurikulum yang relatif berbeda. Muhammad (2017) mengemukakan bahwa di perguruan tinggi, khususnya program studi pendidikan mate matika, pembelajaran matematika lebih dasar dan spesifik. Matematika yang diajarkan di sekolah menengah adalah implementasi teori-teori atau hukum-hukum matematika yang diajarkan di perguruan tinggi.
Berdasarkan kurikulum yang disusun, institusi pendidikan tinggi mencetak lulusannya sesuai dengan yang diharapkan. Pada praktiknya, seorang mahasiswa akan ihadapkan dengan mata kuliah-mata kuliah sebagai pengejawantahan dari kurikulum. Dengan mata kuliah inilah mahasiswa akan belajar me ngembangkan pengetahuan, melatih pola pikir, dan melatih kemandirian. Pada program studi Pendidikan Matematika di Universitas Surya kancana (UNSUR), setiap mahasiswa akan mengambil 57 mata kuliah yang setara dengan 150 SKS. Permasalahan yang ada adalah tidak setiap mata kuliah selalu dilalui mahasiswa dengan baik. Ada saja mahasiswa yang men dapatkan hasil belajar yang kurang baik pada suatu mata kuliah. Salah satu kasus adalah pada mata kuliah Geometri Analitik Ruang. Mata kuliah ini merupakan mata kuliah wajib dengan bobot 3 SKS.

Pada tahun ajaran 2016-2017 mata kuliah Geometri Analitik Ruang diambil oleh 50 orang mahasiswa. Hasilnya, mahasiswa yang memper oleh nilai diatas 3,00 masih kurang dari 70\%. Hal ini terjadi karena mahasiswa kurang me mahami konsep yang disampaikan (mis konsepsi). Kemampuan untuk memahami konsep suatu materi dalam matematika sangatlah penting, dan hingga sekarang masih menjadi bahan penelitian oleh para praktisi pendidikan. Bahkan NCTM 
(2000) menyatakan bahwa semua siswa harus belajar konsep dan proses matematis yang penting dengan memahaminya.

Dalam Adding It Up: Helping Children Learn Mathematis, pemahaman konsep merupa kan salah satu kecakapan matematis yang harus dikuasai setiap orang dalam pembelajaran matematika (Kilpatrik, Swafford, Findell, 2001). Diungkapkan oleh Sudijono (1996) bahwa pemahaman adalah kemampuan seseorang untuk mengerti dan memahami sesuatu setelah sesuatu itu diketahui dan diingat. Menurut Kilpatrick, Swafford, \& Findell (2001) bahwa pemahaman konsep (conceptual understanding) adalah kemampuan dalam memahami konsep, operasi, dan relasi dalam matematika. Kemampuan pemahaman konsep matematis merupakan salah satu aspek penting yang harus dimiliki mahasiswa dalam perkuliahan matematika. Kondisi ini diperlukan untuk memberikan pengertian bahwa materi-materi yang diajarakan kepada para mahasiswa bukanlah hanya sebagai hafalan, namun lebih dari itu. Dengan pemahaman konsep matematis mahasiswa dapat lebih mengerti akan konsep matematika itu sendiri (Muhammad dan Karso, 2017).

Dalam Principles and Standards for School Mathematics oleh NCTM (2000) tertulis, pemahaman konseptual adalah komponen penting dari pengetahuan yang dibutuhkan untuk menghadapi masalah dan pengaturan baru. Selain itu, ketika penilaian berubah tentang fakta atau prosedur yang esensial dalam dunia yang semakin berteknologi, pemahaman konseptual menjadi lebih penting. Pemahaman konsepkonsep esensial akan mempermudah mahasiswa dalam pencapaian kriteria ketuntasan minimal (KKM) yang telah ditetapkan satuan pendidikan. Lemahnya pemahaman konsep-konsep esensial matematis akan mempengaruhi kemampuan matematis lainnya seperti kemampuan penalaran matematis, kemampuan komunikasi matematis, kemampuan koneksi matematis, dan kemampuan pemecahan masalah matematis (Kemendikbud, 2014).

Fenomena mahasiswa kurang memahami konsep yang diajarkan terjadi disebabkan banyak faktor, antara lain dari motivasi, karakteristik mahasiswa, desain pembelajaran, sarana dan prasarana, dosen, maupun lingkungan belajar. Dalam penelitian ini peneliti akan mencoba untuk mencari solusi dari permasalahan tersebut dari sisi desain pem belajaran. Dalam desainpembelajaran tersebut, model yang digunakan dalam penelitian ini adalah model pembelajaran Penemuan Ter bimbing (Guided Discovery Learning). Guided Discovery Learning (GDL) merupakan pengembangan dari model pembelajaran Discovery Learning (DL). Pada prinsipnya DL dan GDL adalah sama, hanya saja GDL lebih menekankan pada proses penemuan konsep oleh pembelajar melalui bimbingan fasilitator.

DL adalah proses belajar yang di dalamnya tidak disajikan suatu konsep dalam bentuk jadi (final), tetapi siswa dituntut untuk mengorganisasi sendiri cara belajarnya dalam menemukan konsep (Kemendikbud, 2014). Bruner mengatakan (Prince dan Felder, 2006) bahwa DL adalah pendekatan berbasis penyelidikan dimana siswa diberi pertanyaan untuk dijawab, masalah untuk dipecahkan, atau serangkaian observasi untuk menjelaskan, dan kemudian bekerja dengan cara yang sebagian besar diatur sendiri untuk menyelesaikan tugas yang ditugaskan dan menarik kesimpulan yang sesuai dari hasil, "menemukan" pengetahuan faktual dan konseptual yang diinginkan dalam proses.

Dengan menginvestigasi sendiri, siswa diharapkan dapat memahami dan mengingat lebih kuat konsep dari materi yang dipelajari. Penerapan GDL berdasarkan rekomendasi dari Prince dan Felder (2006), bahwa mereka tidak merekomendasikan pure Discovery Learning (tanpa bimbingan) untuk kurikulum sarjana terutama sarjana teknik.

Dalam pelaksanaan model GDL, seorang fasilitator harus menempuh langkah-langkah sebagai berikut (Markaban, 2008):

1. Merumuskan masalah.

2. Peserta didik menyusun, memproses, mengorganisir, dan menganlisis data. Guru membimbing.

3. Peserta didik menyusun prakiraan dari hasil analisis yang dilakukannya.

4. Pemeriksaan prakiraan yang telah dibuat peserta didik.

5. Peserta didik menyusun verbalisasi prakiraan.

6. Menyediakan soal latihan untuk memeriksa kebenaran hasil penemuan.

Terdapat beberapa penelitian relevan terkait model GDL. Penelitian yang dilakukan oleh Purnomo (2011), disimpulkan bahwa model penemuan terbimbing lebih baik hasil belajarnya daripada cooperative learning dan cooperative learning lebih baik hasil belajarnya daripada model konvensional. Kemudian penelitian yang 
dilakukan oleh Bani (2011), disimpulkan bahwa pembelajaran matematika dengan metode penemuan terbimbing dapat meningkatkan kemampuan pemahaman dan penalaran matematik siswa.

Selain itu, penelitian yang dilakukan oleh Karim (2011) disimpulkan bahwa pemahaman konsep dan kemampuan berpikir kritis siswa yang mengikuti pembelajaran matematika dengan metode penemuan terbimbing lebih baik dari pada siswa yang mengikuti pembelajaran konvensional ditinjau berdasarkan level sekolah. Penelitian Effendi (2012) disimpulkan bahwa kemampuan representasi dan pemecahan masalah matematis kelas dengan pembelajaran menggunakan metode penemuan terbimbing lebih baik daripada kelas dengan pembelajaran menggunakan metode konvensional.

Berdasarkan hal tersebut penelitian ini bertujuan untuk mengetahui ada/tidaknya peningkatan kemampuan pemahaman konsep matematis mahasiswa dengan model GDL, dan mengetahui respon mahasiswa terhadap model GDL. Selain itu, manfaat dari penelitian ini agar menjadi bukti empiris penerapan model GDL untuk meningkatkan kemampuan pemahaman konsep mahasiswa.

\section{METODE PENELITIAN}

Penelitian ini merupakan penelitian tindakan (action research), karena tindakan yang dilakukan untuk memperbaiki situasi terbatas yang sedang berlangsung. Penelitian ini juga merupakan penelitian kualitatif dan deskriptif, sebab menggali informasi secara terperinci dan lengkap, serta menggambarkan bagaimana suatu teknik pembelajaran diterapkan dan bagaimana hasil yang diinginkan dapat dicapai. Dalam penelitian ini dosen sebagai peneliti dan penulis pertama artikel ini, dimana dosen sangat berperan sekali dalam proses penelitian tindakan kelas. Sedangkan aktivitas pengamatan dilakukan oleh tim peneliti yang lain, yaitu penulis kedua dalam artikel ini yang dibantu oleh seorang mahasiswa tingkat akhir. Tujuan penelitian tindakan kelas ini adalah untuk meningkatkan praktik-praktik pembelajar an di kelas. Dalam kegiatan ini, dosen terlibat langsung secara penuh dalam proses perencana an, tindakan, observasi, dan refleksi.

Penelitian ini mengacu pada perbaikan pembelajaran yang berkesinambungan. Tahapan penelitian tindakan pada suatu siklus meliputi proses perencanaan, tindakan, observasi, dan refleksi. Siklus ini berlanjut dan akan dihentikan jika sesuai dengan kebutuhan dan dirasa sudah cukup. Pada penelitian tindakan kelas ini prosedur kerja secara garis besar dapat dijelaskan dengan Gambar 1 (Arikunto, 2009).

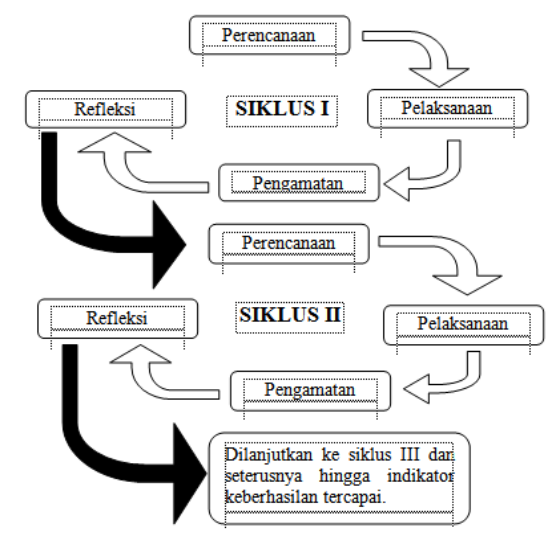

Gambar 1. Model Penelitian Tindakan Kelas

Subjek penelitian ini adalah mahasiswa tingkat dua Program Studi Pendidikan Matematika FKIP-UNSUR Cianjur tahun akademik 2017-2018 yang mengikuti perkuliahan Geometri Analitik Ruang. Terdapat dua kelas mahasiswa yang mengambil perkuliahan Geometri Analitik Ruang. Kelas IIA terdiri dari 19 mahasiswa dan kelas IIB terdiri dari 22 mahasiswa.

Instrumen yang digunakan dalam penelitian ini adalah Lembar Kerja Mahasiswa (LKM) selama pembelajaran, tes siklus, angket, dan lembar observasi. Tes siklus yang diguna-kan dalam penelitian ini adalah tes yang disusun berdasarkan indikator-indikator kemampuan pemahaman konsep matematis. Peneliti hanya mengambil lima dari delapan indikator yang ditetapkan dalam Permendikbud, hal ini menyesuaikan dengan kebutuhan prioritas penelitian dan materi yang diajarkan. Kelima indikator tersebut yaitu: menyatakan ulang konsep; memberikan contoh atau contoh kontra (bukan contoh) dari konsep; mengidentifikasi sifat-sifat operasi atau konsep; menerapkan konsep secara logis; dan mengaitkan berbagai konsep dalam matematika maupun di luar matematika. Tes siklus dilakukan untuk mengetahui tingkat pemahaman konsep matematis maha-siswa setelah mengikuti pembelajaran dengan menggunakan model GDL.

Angket yang diberikan pada akhir pertemuan bertujuan untuk mengetahui respon mahasiswa setelah mengikuti pembelajaran dengan menggunakan model GDL. Lembar 
observasi digunakan untuk mengumpulkan data dari aktivitas mahasiswa selama pembelajaran berlangsung. Data diambil dari setiap pertemuan oleh observer. Hal-hal yang diamati dalam setiap pembelajaran disusun berdasarkan prinsip dan langkah-langkah model GDL.

Data nilai kemampuan pemahaman konsep matematis diperoleh dari nilai tes yang diadakan di setiap akhir siklus. Data nilai kemampuan pemahaman konsep matematis dianalisis secara deskriptif, yaitu dengan menghitung rata-rata nilai tes.

Setelah diperoleh nilai tes kemampuan pemahaman konsep matematis, kemudian nilai digolongkan dengan menggunakan pedoman penafsiran pada Tabel 1 (Arikunto, 2009). Dalam penelitian ini, pemahaman konsep matematis mahasiswa dikatakan meningkat jika rata-rata nilai pada siklus II lebih besar dari siklus I. Untuk menghitung daya serap kelas (DSK) menggunakan rumus sebagai berikut:

$$
\operatorname{DSK}(\%)=\frac{\sum \text { mahasiswa tuntas }}{\sum \text { mahasiswa total }} \times 100 \%
$$

Tabel 1. Kriteria Penggolongan Pemahaman Konsep

\begin{tabular}{|c|c|c|}
\hline Persentase & Kategori & Keterangan \\
\hline $81-100$ & Baik Sekali & Sangat Bisa \\
\hline $61-80$ & Baik & Bisa \\
\hline $41-60$ & Cukup & Cukup Bisa \\
\hline $21-40$ & Kurang & Kurang Bisa \\
\hline $0-20$ & $\begin{array}{c}\text { Kurang } \\
\text { Sekali }\end{array}$ & $\begin{array}{c}\text { Kurang Bisa } \\
\text { Sekali }\end{array}$ \\
\hline
\end{tabular}

Kriteria Ketuntasan Minimum (KKM) perkuliahan telah ditentukan yaitu 70 atau B (3.00). Suatu kelas dikatakan telah mencapai ketuntasan perkuliahan secara klasikal jika dalam kelas terdapat setidaknya $75 \%$ mahasiswa mencapai ketuntasan perkuliahan.

Data tentang aktivitas mahasiswa dalam perkuliahan geometri analitik ruang yang pembelajarannya menggunakan model GDL diperoleh dari observasi yang dilakukan pada setiap siklus. Data ini bertujuan untuk mengetahui proses KBM beserta kekurangannya sehingga dapat diperbaiki dalam pertemuan selanjutnya. Serta untuk mengetahui aktivitas mahasiswa selama proses pembelajaran. Penskoran dilakukan berdasarkan Tabel 2.

Adapun persentase capaian observasi mahasiswa dengan menggunakan rumus sebagai berikut:

$$
\text { Persentase }=\frac{\sum \text { Skor tindakan }}{\sum \text { Skor maksimal }} \times 100 \%
$$

Tabel 2. Skor Observasi Responden

\begin{tabular}{|c|c|}
\hline Dalam angka & Kategori \\
\hline 4 & Sangat Baik \\
\hline 3 & Baik \\
\hline 2 & Cukup \\
\hline 1 & Kurang \\
\hline 0 & Kurang sekali \\
\hline
\end{tabular}

Untuk menentukan predikat tersebut menggunakan konversi lima pada Tabel 3. (Arikunto, 2009). Data respon mahasiswa terhadap model GDL dalam perkuliahan geometri analitik ruang diperoleh dari angket. Derajat penilaian yang digunakan terbagi ke dalam 4 (empat) kategori yang tersusun secara bertingkat, mulai dari Sangat Tidak Setuju (STS), Tidak Setuju (TS), Setuju (S), dan Sangat Setuju (SS). Adapun penilaian dan pengambilan kesimpulan disajikan pada Tabel 4.

\section{Tabel 3. Tolak Ukur Predikat Observasi Responden}

\begin{tabular}{|c|c|}
\hline Persentase & Kategori \\
\hline $81 \%-100 \%$ & Baik Sekali \\
\hline $61 \%-80 \%$ & Baik \\
\hline $41 \%-60 \%$ & Cukup \\
\hline $21 \%-40 \%$ & Kurang \\
\hline $0 \%-20 \%$ & Kurang Sekali \\
\hline
\end{tabular}

Tabel 4. Tabel Klasifikasi Angket

\begin{tabular}{|c|c|c|c|c|}
\hline Pernyataan & SS & S & TS & STS \\
\hline Positif & + & + & - & - \\
\hline Negatif & - & - & + & + \\
\hline
\end{tabular}

Secara kumulatif pengambilan kesimpulan per pernyataan ditentukan oleh modus dari respon seluruh mahasiswa terhadap pernyataan tersebut. Sedangkan untuk pengambilan kesimpulan secara keseluruhan angket ditentu kan berdasarkan modus dari rata-rata persentase respon mahasiswa, dan diklasifikasikan berdasarkan Tabel 5 .

Tabel 5. Klasifikasi Perhitungan Persentasi Angket Tiap Kategori

\begin{tabular}{|c|c|}
\hline Besar Persentasi & Interpretasi \\
\hline $0 \%$ & Tidak seorang pun \\
\hline $1 \%-25 \%$ & Sebagian kecil \\
\hline $26 \%-49 \%$ & Hampir setengahnya \\
\hline
\end{tabular}




\begin{tabular}{|c|c|}
\hline $50 \%$ & Setengahnya \\
\hline $51 \%-75 \%$ & Sebagian besar \\
\hline $76 \%-99 \%$ & Pada umumnya \\
\hline $100 \%$ & seluruhnya \\
\hline
\end{tabular}

Penelitian ini dikatakan berhasil, apabila $75 \%$ mahsiswa mencapai nilai $\geq 70$ atau B (nilai KKM Perkuliahan) pada tes kemampuan pemahaman konsep matematis yang dilaksana kan pada penelitian ini.

\section{HASIL DAN PEMBAHASAN}

Berdasarkan tes siklus I didapatkan data mentah yang dapat digunakan sebagai gambaran kasar kondisi kemampuan pemahaman konsep mahasiswa. Dari Tabel 6. dapat dilihat bahwa nilai rata-rata kedua kelas relatif sama dengan standar deviasi yang juga tidak terlalu jauh selisihnya walaupun nilainya cukup besar, sehingga patut diduga bahwa karakteristik kedua kelas adalah sama. Standar deviasi yang besar mengindikasikan keheterogenan kemampuan pemahaman konsep mahasiswa. Persentase tingkat pemahaman konsep mahasiswa siklus I dapat dilihat pada Gambar 2 dan Gambar 3.

Tabel 6. Statistik Deskriptif Tes Siklus I

\begin{tabular}{|c|c|c|}
\hline No. & $\mathbf{1}$ & $\mathbf{2}$ \\
\hline Kelas & IIA & IIB \\
\hline Jumlah & 19 & 22 \\
\hline $\begin{array}{c}\text { Skor } \\
\text { Ideal }\end{array}$ & 100 & 100 \\
\hline Max & 100 & 100 \\
\hline Min & 2 & 9 \\
\hline Rerata & 52.90 & 49.91 \\
\hline SD & 27.45 & 24.85 \\
\hline
\end{tabular}

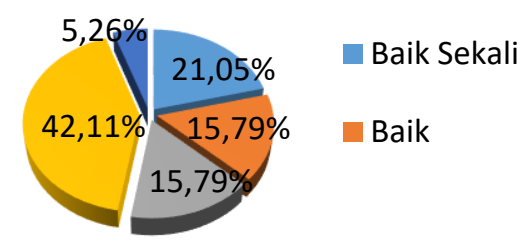

Gambar 2. Persentase Tingkat Pemahaman Konsep Matematis Siklus I Kelas IIA

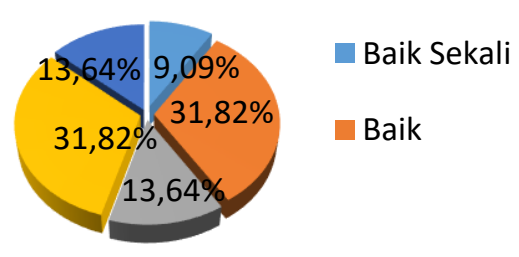

Gambar 3. Persentase Tingkat Pemahaman

Konsep Matematis Siklus I Kelas IIB

Berdasarkan tes siklus II didapatkan data seperti pada Tabel 7. Dapat terlihat bahwa skor minimum dan rata-rata kelasnya meningkat dengan nilai standar deviasi yang menurun. Persentase tingkat pemahaman konsep mahasiswa siklus II dapat dilihat pada diagram pie sebagai berikut.

Tabel 7. Statistik Deskriptif Tes Siklus II

\begin{tabular}{|c|c|c|}
\hline No. & $\mathbf{1}$ & $\mathbf{2}$ \\
\hline Kelas & IIA & IIB \\
\hline Jumlah & 19 & 22 \\
\hline $\begin{array}{c}\text { Skor } \\
\text { Ideal }\end{array}$ & 100 & 100 \\
\hline Max & 96 & 93 \\
\hline Min & 43 & 46 \\
\hline Rerata & 75.58 & 71.36 \\
\hline SD & 13.97 & 14.19 \\
\hline
\end{tabular}

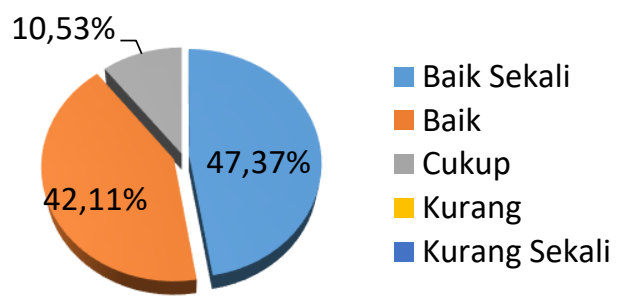

Gambar 4. Persentase Tingkat Pemahaman Konsep Matematis Siklus II Kelas IIA

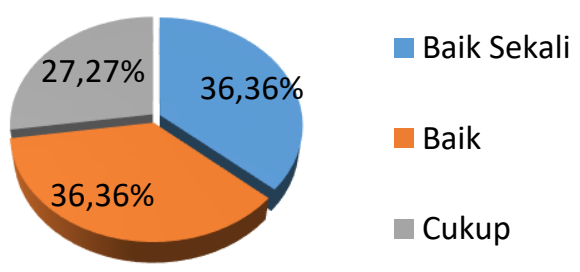

Gambar 5. Persentase Tingkat Pemahaman Konsep Matematis Siklus II Kelas IIB

Berdasarkan Tabel 6 dan Tabel 7 secara eksplisit nilai tersebut mengalami peningkatan, sehingga dapat disimpulkan bahwa kemampuan 
pemahaman konsep matematis mahasiswa meningkat dari siklus I ke siklus II. Dari hasil tes yang dilakukan pada setiap siklus untuk DSK dan nilai rata-rata mahasiswa dapat ditunjukan pada Tabel 8. Kriteria Ketuntasan Minimum perkuliahan (KKM) telah ditentukan yaitu 70 atau B (dengan nilai mutu minimal 3). Suatu kelas dikatakan telah mencapai ketuntasan perkuliahan secara klasikal jika dalam kelas terdapat $75 \%$ mahasiswa mencapai ketuntasan perkuliahan. Hasil pada siklus II $77.3 \%$ maha siswa mendapatkan nilai diatas 70 , sehingga memenuhi indikator keberhasilan.

Tabel 8. Daya Serap Kelas dan Nilai Rata-rata Siswa Pada Setiap Siklus

\begin{tabular}{|c|c|c|c|c|}
\hline \multirow{2}{*}{ Siklus } & \multicolumn{2}{|c|}{ Kelas IIA } & \multicolumn{2}{c|}{ Kelas IIB } \\
\cline { 2 - 5 } & DSK & $\begin{array}{c}\text { Rata- } \\
\text { rata }\end{array}$ & DSK & $\begin{array}{c}\text { Rata- } \\
\text { rata }\end{array}$ \\
\hline I & $31,58 \%$ & 52.90 & $18,18 \%$ & 49.91 \\
\hline II & $78,95 \%$ & 75.58 & $77,27 \%$ & 71.36 \\
\hline
\end{tabular}

Kegiatan observasi ditujukan untuk mengukur sejauh mana aktivitas belajar selama pembelajaran berlangsung dengan menggunakan model GDL. Observasi dilakukan pada setiap pertemuan. Pada kegiatan ini aspek yang diamati diantaranya:

1. Terdapat interaksi dalam pembelajaran dengan dosen (disimbolkan A),

2. Terdapat interaksi belajar dengan teman sejawat lainnya (disimbolkan B),

3. Membuat prakiraan dalam LKM (disim bolkan C),

4. Mengerjakan soal dengan sungguh-sungguh (disimbolkan D),

5. Memperhatikan penjelasan dosen sebagai konfirmasi atas kebenaran prakiraan (di simbolkan E), dan

6. Bersemangat dan antusias saat belajar (di simbolkan F).

Berikut ini adalah rekapitulasi hasil observasi selama dua siklus untuk kedua kelas beserta interpretasi kategori sebagai simpulan.

Tabel 9. Persentase Hasil Observasi

\begin{tabular}{|c|c|c|c|}
\hline No & $\begin{array}{c}\text { Aspek } \\
\text { yang } \\
\text { Diamati }\end{array}$ & $\begin{array}{c}\text { Rerata } \\
\text { IIA dan IIB }\end{array}$ & Kategori \\
\hline 1 & A & $76.19 \%$ & Baik \\
\hline 2 & B & $86.65 \%$ & Baik Sekali \\
\hline 3 & C & $72.39 \%$ & Baik \\
\hline 4 & D & $76.48 \%$ & Baik \\
\hline
\end{tabular}

\begin{tabular}{|c|c|c|c|}
\hline 5 & E & $77.21 \%$ & Baik \\
\hline 6 & F & $70.12 \%$ & Baik \\
\hline
\end{tabular}

Angket terdiri dari delapan butir pernya taan dengan empat pernyataan bersifat positif dan empat pernyataan bersifat negatif. Matriks hasil pengisian angket oleh mahasiswa terhadap pembelajaran menggunakan model GDL ter tuang pada Tabel 10. Berdasarkan Tabel 10. bahwa sikap mahasiswa terhadap model GDL pada umumnya positif.

Tabel 10. Persentase Respon Mahasiswa Terhadap Model GDL

\begin{tabular}{|c|c|c|c|c|}
\hline \multirow{2}{*}{ No } & \multirow{2}{*}{ Sifat } & \multicolumn{2}{|c|}{ Respon (\%) } & \multirow{2}{*}{ Keterangan } \\
\cline { 3 - 5 } 1 & + & $82.93 \%$ & $17.07 \%$ & $\begin{array}{c}\text { Pada } \\
\text { Umumnya } \\
\text { Positif }\end{array}$ \\
\hline 2 & + & $90.24 \%$ & $9.76 \%$ & $\begin{array}{c}\text { Pada } \\
\text { Umumnya } \\
\text { Positif }\end{array}$ \\
\hline 3 & + & $87.80 \%$ & $12.20 \%$ & $\begin{array}{c}\text { Pada } \\
\text { Umumnya } \\
\text { Positif }\end{array}$ \\
\hline 4 & + & $75.61 \%$ & $24.39 \%$ & $\begin{array}{c}\text { Sebagian } \\
\text { Besar Positif }\end{array}$ \\
\hline 5 & - & $73.17 \%$ & $26.83 \%$ & $\begin{array}{c}\text { Sebagian } \\
\text { Besar Positif }\end{array}$ \\
\hline 6 & - & $78.05 \%$ & $21.95 \%$ & $\begin{array}{c}\text { Pada } \\
\text { Umumnya } \\
\text { Positif }\end{array}$ \\
\hline 7 & - & $85.37 \%$ & $14.63 \%$ & $\begin{array}{c}\text { Pada } \\
\text { Umumnya } \\
\text { Positif }\end{array}$ \\
\hline 8 & - & $70.73 \%$ & $29.27 \%$ & $\begin{array}{c}\text { Sebagian } \\
\text { Besar Positif }\end{array}$ \\
\hline Rata-rata & $\mathbf{8 0 . 4 9}$ & $\mathbf{1 9 . 5 1 \%}$ & $\begin{array}{c}\text { Pada } \\
\text { Umumnya } \\
\text { Positif }\end{array}$ \\
\hline
\end{tabular}

Berdasarkan hasil analisis data kemam puan pemahaman konsep mahasiswa pada setiap siklusnya mengalami peningkatan. Untuk kelas IIA dengan peningkatan rata-rata dari siklus I ke siklus II sebesar 22,68 (42,89\%). Sedangkan untuk kelas IIB peningkatan rata-rata dari siklus I ke siklus II sebesar 21,45 (42,99\%). Kemampuan pemahaman konsep dalam penelitian ini dibagi dalam lima tingkatan pemahaman, mulai dari "baik sekali", "baik", "cukup", "kurang", dan "kurang sekali". Dari hasil tes siklus I, tingkat pemahaman konsep mahasiswa dominan pada tingkatan "kurang" yaitu $42,11 \%$ untuk kelas IIA, dan 31,82\% untuk kelas IIB (lengkapnya pada Gambar 2. Dan Gambar 3.). Ini terjadi dikarenakan materi 
Geometri Analitik Ruang yang menuntut kemampuan khayal yang lebih. Ditambah proses pembelajaran yang hanya menggunakan media dua dimensi untuk menjelaskan tiga dimensi. Sehingga pada refleksi awal (siklus I) disa rankan pembelajaran menggunakan multimedia, salah satunya perangkat lunak Geogebra yang dapat membantu mahasiswa menggambarkan fisik dimensi tiga. Selain itu, belum terbiasanya mahasiswa menggunakan LKM dengan bentuk terstruktur dan sistematis dengan redaksi yang memberikan stimulus pada mahasiswa sehingga dapat memberikan respon yang diharapkan. Akibatnya, dalam prakteknya sebagian besar alokasi waktu yang direncanakan habis untuk menyelesaikan LKM. Hal ini yang menjadi catatan untuk peneliti.

Berdasarkan hasil tes dan refleksi siklus I, peneliti melakukan perbaikan pada beberapa hal yang telah disebutkan sebelumnya untuk diperbaiki pada siklus II. Sehingga hasilnya tingkat pemahaman konsep mahasiswa dominan pada tingkat "baik sekali" dengan $47,37 \%$ untuk kelas IIA, dan $36,36 \%$ untuk kelas IIB (lengkapnya pada Gambar 4. Dan Gambar 5.). Berdasarkan Gambar 4 dan Gambar 5 tidak ada mahasiswa yang berada pada tingkat pemahaman "kurang" atau "kurang sekali". Hal ini menunjukkan bahwa langkah perbaikan berda sarkan hasil tes dan refleksi siklus I telah tepat.

Bila ditinjau berdasarkan proses pem belajaran, penerapan model GDL membantu meningkatkan kemampuan pemahaman konsep mahasiswa. Hal ini bisa terjadi karena siswa dapat berpartisipasi aktif dalam pembelajaran yang disajikan. Terbukti dalam hasil observasi (Tabel 9), bahwa terdapat interaksi antara mahasiswa dengan dosen dalam pembelajaran dengan kategori "baik" $(76,19 \%)$, dan terdapat interaksi belajar dengan teman sejawat lainnya dengan kategori "baik sekali" (86,65\%). Selain itu, karena model GDL menanamkan sikap inquiry (mencaritemukan), dan mendukung kemampuan problem solving siswa. Model GDL secara praktis memberikan keleluasaan untuk berdiskusi de-ngan dosen dan teman sejawat, sehingga mahasiswa lebih aktif. Pernyataan yang mendukung hal ini dikemukakan oleh Bani (2011), metode penemuan terbimbing dapat meningkatkan kemampuan pemahaman.

Tingkat ketuntasan mahasiswa berdasar kan Daya Serap Kelas mengalami peningkatan, untuk kelas IIA dari $31,58 \%$ pada siklus I naik menjadi $78,95 \%$ pada siklus II. Untuk kelas IIB dari $18,18 \%$ pada siklus I naik menjadi $77,27 \%$ pada siklus II. Berdasarkan indikator keberha silan bahwa DSK pada kedua kelas meningkat menjadi lebih besar dari 75\%, hal ini menun jukkan bahwa pembelajaran dengan Model GDL dapat meningkatkan kemampuan pemahaman konsep matematis mahasiswa.

Selain ditinjau dari kemampuan pema haman, berdasarkan hasil penelitian, data respon mahasiswa yang diperoleh dari angket skala sikap disimpulkan bahwa pembelajaran dengan model GDL mendapat respon pada umumnya positif atau respon yang baik dari mahasiswa terhadap perkuliahan Geometri Analitik Ruang. Jika dihubungkan dengan butir pernyataannya secara eksplisit terlihat bahwa siswa merasa bersemangat belajar, merasa lebih fokus dan lebih memahami materi dengan model GDL. Selain itu suasana kelas menjadi aktif sehingga mahasiswa tidak merasa bosan untuk belajar.

\section{KESIMPULAN}

Penerapan model GDL dapat meningkatkan kemampuan pemahaman konsep matematis mahasiswa ditinjau dari lima indikator: 1) menyatakan ulang konsep, 2) memberikan contoh atau contoh kontra (bukan contoh) dari konsep, 3) mengidentifikasi sifatsifat operasi atau konsep, 4) menerapkan konsep secara logis, 5) mengaitkan berbagai konsep dalam matematika maupun di luar matematika. Hal ini dapat dilihat dari rata-rata hasil tes siklus mahasiswa mening-kat. Selain itu, daya serap klasikal yang dipero-leh dari siklus I dan II pun mengalami pening-katan.

Berdasarkan angket yang disebarkan, da pat disimpulkan bahwa respon mahasiswa terha dap pembelajaran matematika dengan model GDL pada umumnya bersikap positif atau respon yang baik dari mahasiswa terhadap perku-liahan Geometri Analitik Ruang dengan menggunakan model GDL.

\section{DAFTAR PUSTAKA}

Arikunto, S., 2009. Dasar-dasar Evaluasi Pendidikan (Edisi Revisi). Jakarta: Bumi Aksara.

Bani, A., 2011. Meningkatkan kemampuan pemahaman dan penalaran matematik siswa sekolah menengah pertama melalui pembelajaran penemuan terbimbing, SPS UPI, Bandung. UPI: Bandung. 
Effendi, L.A., 2012. Pembelajaran matematika dengan metode penemuan terbimbing untuk meningkatkan kemampuan representasi dan pemecahan masalah matematis siswa SMP. Jurnal Penelitian Pendidikan, 13(2).

Karim, A., 2011. Penerapan metode penemuan terbimbing dalam pembelajaran matematika untuk meningkatkan pemahaman konsep dan kemampuan berpikir kritis siswa sekolah dasar. Jurnal Pendidikan.

Kemendikbud, 2014. Materi Pelatihan Implemetasi Kurikulum 2013 Guru Mata Pelajaran Matematika SMA/MA/SMK/ $M A K$. Jakarta: Kemendikbud.

Kemendikbud, 2014. Permendikbud No.59 Tahun 2014 tentang Pedoman Mata pelajaran Matematika SMA/MA/SMK/MAK. Jakarta: Kemendikbud.

Kilpatrik J., Swafford J., Findell B., (Eds), 2001. Adding it Up : Helping Children Learn Mathematics. Washington, DC: National Academy Press.

Markaban, 2008. Model Penemuan Terbimbing Pada Pembelajaran Matematika SMK. Yogyakarta: PPPPTK Matematika.

Muhammad, G.M., Karso, 2017. Penerapan Model Pembelajaran Problem Based
Learning (PBL) Untuk Meningkatkan Pemahaman Konsep Matematis Mahasiswa. Prosiding Seminar Nasional Pendidikan Matematika UHAMKA 2017, 1, pp.1-5

Muhammad, G.M., 2017. Analisis Kemampuan Penalaran Matematis Mahasiswa Pada Mata Kuliah Struktur Aljabar II (Teori Gelanggang). PRISMA, 6(1), pp.66-78.

National Council of Teacher Mathematics (NCTM), 2000. Principles and Standards for School Mathematics. USA : NCTM.

Prince, M.J. and Felder, R.M., 2006. Inductive teaching and learning methods: Definitions, comparisons, and research bases. Journal of engineering education, 95(2), pp.123-138.

Purnomo, Y.W., 2011. Keefektifan Model Penemuan Terbimbing dan Cooperative Learning pada Pembelajaran Matematika. Jurnal Kependidikan: Penelitian Inovasi Pembelajaran, 41(1).

Sudijono A., 1996. Pengantar Evaluasi Pendidikan. Jakarta: PT.Raja Grafindo. Persada.

Sugiyono, 2007. Statistika Untuk Penelitian. Bandung: Alfabet 